\begin{tabular}{|c|c|c|}
\hline & $\begin{array}{l}\text { JURNAL } \\
\text { DENTI ITI }\end{array}$ & $\begin{array}{l}\text { e-ISSN : 2407-795X } \\
\text { p-ISSN : } 2460-2582\end{array}$ \\
\hline $\mathbb{N}^{-P P P}$ & & $\begin{array}{c}\text { Vol 2, No, } 1 \\
\text { Januari } 2016\end{array}$ \\
\hline
\end{tabular}

\title{
PENGARUH MODEL PEMBELAJARAN KOOPERATIF TERHADAP HASIL BELAJAR KOGNITIF DITINJAU DARI KEMAMPUAN AKADEMIK MAHASISWA
}

\author{
Fahruddin $^{1}$, A. Wahab Jufri ${ }^{1}$, Jamaluddin ${ }^{1}$ \\ Program Studi Magister Pendidikan IPA, Program Pascasarjana, Universitas Mataram ${ }^{123}$ \\ Email : faha_fahruddin@yahoo.co.id
}

\begin{abstract}
Key Words
STAD,

Jigsaw II,

$T G T$,

academic

ability,

cognitive

learning

outcomes

Abstract

This research aims to determine the effect of cooperative learning on cognitive learning outcomes in terms of students' academic abilities. This study was aquasi-experimental research design with non-equivalent pretest-posttest control group design with $2 \times 4$ factorial design. The study population was a student of biology education STKIP Bima semester IV, total of 8 classes with a number of 336 students. Samples were obtained through a simple random sampling technique, of which there are 8 classes taken 4 classes as the sample with 168 students.The research instrument is a cognitive achievement test. The data were analyze dusing statistical techniques Anacova two paths. The results showed that 1) There is influence of cooperative learning model type STAD, Jigsaw II, and the TGT to the cognitive achievement of students ( $p<0.05), 2)$ There is influence of academic ability on the cognitive achievement of students ( $p<0.05), 3)$ There is no influence to interaction effect between cooperative learning model type STAD, Jigsaw II, and TGT with academic ability of the student cognitive learning outcomes ( $p>0.05), 4)$ Different test results show that the cooperative learning model TGT significant differences in their effects oncognitive learning outcomes, compared with Jigsaw II, and STAD (coefficient positively and sig. <0,05).
\end{abstract}

\begin{tabular}{|c|c|}
\hline Kata Kunci & Abstrak \\
\hline $\begin{array}{l}\text { STAD, } \\
\text { Jigsaw II, } \\
\text { TGT, } \\
\text { Kemampuan } \\
\text { Akademik, } \\
\text { Hasil Belajar } \\
\text { Kognitif }\end{array}$ & $\begin{array}{l}\text { Penelitian ini bertujuan untuk mengetahui pengaruh model pembelajaran kooperatif } \\
\text { terhadap hasil belajar kognitif ditinjau dari kemampuan akademik mahasiswa. Penelitian } \\
\text { ini adalah penelitian eksperimen semu dengan desain pretest-posttest non equivalen } \\
\text { control group design dengan rancangan faktorial } 2 \times 4 \text {. Populasi penelitian adalah } \\
\text { mahasiswa program studi pendidikan Biologi semester IV STKIP Bima, sebanyak } 8 \text { kelas } \\
\text { dengan jumlah } 336 \text { mahasiswa. Sampel penelitian diperoleh melalui teknik simple } \\
\text { random sampling, dari } 8 \text { kelas diambil } 4 \text { kelas sebagai sampel dengan jumlah mahasiswa } \\
\text { sebanyak } 168 \text { orang. Instrumen penelitian berupa tes hasil belajar kognitif. Data hasil } \\
\text { penelitian dianalisis dengan teknik statistik Anacova dua jalur. Hasil penelitian } \\
\text { menunjukkan bahwa 1) Ada pengaruh model pembelajaran kooperatif tipe STAD, Jigsaw } \\
\text { II, dan TGT terhadap hasil belajar kognitif mahasiswa (p<0,05), 2) Ada pengaruh } \\
\text { kemampuan akademik terhadap hasil belajar kognitif mahasiswa (p<0,05), 3) Tidak ada } \\
\text { pengaruh interaksi model pembelajaran kooperatif tipe STAD, Jigsaw II, dan TGT } \\
\text { dengan kemampuan akademik terhadap hasil belajar kognitif mahasiswa (p>0,05), 4) } \\
\text { Hasil uji beda menunjukkan bahwa model pembelajaran kooperatif tipe TGT yang } \\
\text { signifikan perbedaan pengaruhnya terhadap hasil belajar kognitif, dibandingkan dengan } \\
\text { tipe Jigsaw II, dan STAD (berkoofisien positif dan sig.<0,05). }\end{array}$ \\
\hline
\end{tabular}


PENDAHULUAN

\section{Undang-Undang Republik}

Indonesia Nomor 12 tahun 2012 pasal 4 Tentang fungsi Pendidikan Tinggi mengamanatkan antara lain; a) mengembangkan kemampuan dan membentuk watak serta peradaban bangsa yang bermartabat dalam rangka mencerdaskan kehidupan bangsa; b) mengembangkan Sivitas Akademika yang inovatif, responsif, kreatif, terampil, berdaya saing, dan kooperatif melalui pelaksanaan Tridharma; c) mengembangkan Ilmu Pengetahuan dan Teknologi dengan memperhatikan dan menerapkan nilai Humaniora. (Lembaran Negara RI, 2012).

Pembelajaran di perguruan tinggi yang berlangsung saat sekarang perlu dikaji untuk dapat dipetakan pola keragamannya. Oleh karenanya perlu dilakukan perubahan dalam proses pembelajaran di perguruan tinggi tidak lagi berbentuk Teacher-Centered-ContentOriented (TCCO), tetapi bergeser dengan menggunakan prinsip Student-CenteredLearning (SCL) yang disesuaikan dengan keadaan perguruan tingginya. TCCO atau pembelajaran yang berpusat pada pendidik merupakan model pembelajaran konvensional yang dapat memberikan dampak negatif pada mahasiswa diantaranya mahasiswa menjadi pasif, kurang kreatif dan jika mengandalkan penjelasan dari pendidik saja, maka informasi yang akan diterima sangat terbatas dan tidak dapat menumbuhkembangkan proses partisipasi aktif dalam pembelajaran (Dikti, 2008).

Berdasarkan pengamatan dan pengalaman pendidik pengampu mata kuliah bahwa proses pembelajaran yang berlangsung di STKIP Bima saat ini belum seluruhnya berpusat pada mahasiswa dan masih banyak menggunakan prinsip pembelajran Teacher-Centred-Content Oriented (TCCO), dengan masih banyaknya pendidik yang menggunakan metode ceramah, tanya jawab, mengerjakan tugastugas dan diskusi kelompok dengan cara konvesional dalam menyampaikan materi, khususnya di Program Studi Pendidikan Biologi. Metode ceramah, tanya jawab dan diskusi yang dikombinasikan oleh pendidik selama ini bukan berarti tidak cocok digunakan tetapi penggunaan metode tersebut yang mendominasi dalam setiap proses pembelajaran menyebabkan mahasiswa merasa bosan, jenuh, dan menurunnya motivasi dan hasil belajar mahasiswa. Keadaan seperti ini dapat 
menyebabkan kegiatan belajar mahasiswa menjadi kurang bermakna, dan hasil belajar yang rendah. Hal ini terlihat pula pada nilai akhir semester ganjil mata kuliah invertebrata tahun 2014 bahwa proporsi mahasiswa yang mendapatkan nilai $\mathrm{A} / 4$ sebesar $6 \%$, nilai $\mathrm{B} / 3$ sebesar 20\%, nilai $\mathrm{C} / 2$ sebesar $37 \%$, nilai $\mathrm{D} / 1$ sebesar $24 \%$, dan $\mathrm{E} / 0$ sebesar $13 \%$ dari jumlah 160 mahasiswa yang aktif kuliah (Abbassyahrir, komunikasi pribadi). Data ini menunjukkan bahwa sebagian besar mahasiswa memperoleh nilai $\mathrm{D}$ dan $\mathrm{E}$ dengan predikat kurang dan sangat kurang. Dengan demikian perlu diterapkan model pembelajaran yang efektif yang dapat meningkatkan hasil belajar mahasiswa.

Salah satu upaya untuk meningkatkan mutu pembelajaran tersebut yaitu dengan melakukan perbaikan pada proses pembelajaran di kelas dengan model pembelajaran berpusat pada mahasiswa atau bergeser kepada prinsip Student-Centered-Learning (SCL), dengan menfokuskan pada tercapainya kompetensi mahasiswa yang mandiri dan kompeten. Hal ini berarti mahasiswa harus didorong untuk memiliki motivasi dalam diri mereka sendiri, kemudian berupaya untuk mencapai hasil belajar yang diinginkan. Adapun kondisi riil mahasiswa yang ada di STKIP Bima antara lain: a) mahasiswa yang memiliki kemampuan akademik yang berbeda dengan dilatar belakangi sekolah yang berbeda, b) mahasiswa yang berasal dari daerah asal yang berbedabeda, c) banyaknya jumlah mahasiswa pada tiap kelas, d) banyaknya jenis kelamin perempuan pada tiap kelas. Dari keadaan yang heterogen itu maka perlu dikembangkan suatu model pembelajaran yang dapat mengorganisasikan mahasiswa untuk bekerja dan belajar kelompok, sehingga dapat menerapkan komunikasi interpersonal serta keterlibatan kelompok diantara peserta didik. Salah satu model pembelajaran yang relevan sesuai dengan keadaan mahasiswa di atas yaitu dengan menerapkan model pembelajaran kooperatif.

Menurut Tinzmann, et al 1990; Ahern-Rindell 1999, dalam Jufri (2010) menyatakan pembelajaran kooperatif merupakan salah satu model pembelajaran di mana peserta didik diorganisasikan untuk bekerja dan belajar dalam kelompok yang memiliki aturan-aturan tertentu. Peserta didik dikondisikan untuk belajar bersama-sama dalam kelompok yang heterogen dari segi akademik, etnis, dan jenis kelamin untuk membahas pertanyaan-pertanyaan atau masalahmasalah yang terkait dengan pelajaran yang dihadapkan kepadanya.

Dari beberapa tipe model pembelajaran kooperatif diantaranya tipe 
Student Team Achievement Division (STAD), Jigsaw II, dan Team-GamesTournaments (TGT), akan dijadikan variabel penelitian yang disebabkan karena ketiga tipe pembelajaran kooperatif ini mempunyai sintaks yang hampir sama, memberikan tanggung jawab individu, memberikan kesempatan yang sama untuk sukses, dan memberikan penguatan berupa penghargaan pada kelompok yang mendapat skor tertinggi (Huda, 2012). Model pembelajaran kooperatif tersebut akan dikombinasikan dengan kemampuan akademik yang akan dijadikan sebagai varibel moderator untuk mengetahui ada atau tidaknya pengaruh terhadap hasil belajar kognitif mahsiswa.

Adapun tujuan penelitian ini adalah:1) Untuk mengetahui pengaruh model pembelajaran kooperatif tipe STAD, Jigsaw II, dan TGT terhadap hasil belajar kognitif mahasiswa program studi pendidikan Biologi semester IV STKIP Bima. 2) Untuk mengetahui pengaruh kemampuan akademik terhadap hasil belajar kognitif mahasiswa program studi pendidikan Biologi semester IV STKIP Bima. 3) Untuk mengetahui pengaruh interaksi antara model pembelajaran kooperatif tipe STAD, Jigsaw II dan TGT dengan kemampuan akademik terhadap hasil belajar kognitif mahasiswa program studi pendidikan Biologi semester IV STKIP Bima.

\section{METODE}

Penelitian ini dikategorikan sebagai penelitian eksperimen semu (quasi experiment). Desain yang dipergunakan adalah pretes-posttes non equivalen control group design (Sugiyono, 2012). Rancangan penelitian ini menggunakan model faktorial $2 \times 4$.

Tabel 1. Rancangan Pelaksanaan Penelitian Eksperimen (Faktorial 2 x 4)

\begin{tabular}{l|cccc}
\multirow{2}{*}{$\begin{array}{c}\text { Kemampuan } \\
\text { Akademik }(\mathrm{X})\end{array}$} & Kooperatif tipe & Kooperatif tipe & Kooperatif tipe & Konvensional \\
STAD $\left(\mathrm{Y}_{1}\right)$ & Jigsaw II $\left(\mathrm{Y}_{2}\right)$ & TGT $\left(\mathrm{Y}_{3}\right)$ & $\left(\mathrm{Y}_{4}\right)$ \\
\hline Tinggi $\left(\mathrm{X}_{1}\right)$ & $\mathrm{X}_{1} \mathrm{Y}_{1}$ & $\mathrm{X}_{1} \mathrm{Y}_{2}$ & $\mathrm{X}_{1} \mathrm{Y}_{3}$ & $\mathrm{X}_{1} \mathrm{Y}_{4}$ \\
Rendah $\left(\mathrm{X}_{2}\right)$ & $\mathrm{X}_{2} \mathrm{Y}_{1}$ & $\mathrm{X}_{2} \mathrm{Y}_{2}$ & $\mathrm{X}_{2} \mathrm{Y}_{3}$ & $\mathrm{X}_{2} \mathrm{Y}_{4}$ \\
\hline
\end{tabular}

\section{Keterangan:}

$\mathrm{X}_{1} \mathrm{Y}_{1}$ : Perlakuan kemampuan akademik tinggi dengan model pembelajaran kooperatif tipe STAD $\mathrm{X}_{2} \mathrm{Y}_{1}$ : Perlakuan kemampuan akademik rendah dengan model pembelajaran kooperatif tipe STAD $\mathrm{X}_{1} \mathrm{Y}_{2}$ : Perlakuan kemampuan akademik tinggi dengan model pembelajaran kooperatif tipe Jigsaw II $\mathrm{X}_{2} \mathrm{Y}_{2}$ : Perlakuan kemampuan akademik rendah dengan model pembelajaran kooperatif tipe Jigsaw II $\mathrm{X}_{1} \mathrm{Y}_{3}$ : Perlakuan kemampuan akademik tinggi dengan model pembelajaran kooperatiftipe TGT $\mathrm{X}_{2} \mathrm{Y}_{3}$ : Perlakuan kemampuan akademik rendah dengan model pembelajaran kooperatif tipe TGT $\mathrm{X}_{1} \mathrm{Y}_{4}$ : Perlakuan kemampuan akademik tinggi dengan model pembelajaran konvesional $\mathrm{X}_{2} \mathrm{Y}_{4}$ : Perlakuan kemampuan akademik rendah dengan model pembelajaran konvensional 
Populasi penelitian ini adalah seluruh mahasiswa semester IV Program Studi Pendidikan Biologi STKIP Bima Tahun Akademik 2013/2014 yang berjumlah 336 orang mahasiswa yang terbagi ke dalam delapan kelas. Penentuan sampel dilakukan dengan teknik Simple Random sampling, dari 8 kelas menjadi 4 kelas yang dijadikan sampel dengan berjumlah 168 mahasiswa yang dilaksanakan pada bulan Mei sampai Juni 2014.

\section{Teknik Pengumpulan Data.}

Data hasil belajar kognitif diperoleh melalui tes yang diberikan kepada mahasiswa sebagai kelas perlakuan sebanyak dua kali yaitu sebelum (pretes) dan sesudah (posttes) rangkaian pembelajaran. Instrumen penelitian ini berupa soal pilihan ganda dan soal uraian.

\section{Teknik Analisis Data}

Analisis instrumen pada hasil belajar kognitif yaitu dengan menggunakan pengskoran tes soal pilihan ganda dan soal uraian. Tiap-tiap skor mentah diubah ke bentuk nilai dengan menggunakan skala 0-100 dengan rumus sebagai berikut:

Nilai $=\frac{\text { Skor yang diperoleh }}{\text { Skor maksimum soal }} \times 100$

(Sugiyono, 2012)

\section{Uji Hipotesis}

Uji prasyarat dilakukan sebelum uji hipotesis yaitu uji normalitas dan homogenitas data sebagai prasyarat uji statistik parametris. Data-data yang normal dan homogen dilanjutkan dengan uji Anacova dua jalur (dua faktor) yaitu untuk mengetahui pengaruh utama dan interaksi dari tipe model pembelajaran kooperatif dan kemampuan akademik yang diterapkan terhadap variabel terikat. Kemudian untuk melihat pengaruh perbedaan dari perlakuan antar model pembelajaran dan perlakuan antar interaksi model pembelajaran dengan kemampuan akademik, maka dilakukan uji lanjut dengan LSD (Least Significant Defference).

Untuk mempermudah analisis uji hipotesis yaitu dengan menggunakan SPSS versi 18 for window dengan taraf signifikan 5\% (Trihendardi, 2009). Kovarian yang digunakan dalam penelitian ini adalah pretest.

\section{HASIL DAN PEMBAHASAN}

Hasil uji normalitas diperoleh nilai sig. $(0,062)$ dan homogenitas diperoleh nilai sig. $(0,193)$ terhadap hasil belajar kognitif. Hal ini menunjukkan bahwa nilai Sig. (p) > 0,05 yang berarti telah memenuhi uji prasyarat yang kemudian akan dilanjutkan dengan uji hipotesis. 


\section{Uji Hipotesis}

Uji hipotesis dengan menggunakan analisis uji Anakova dua jalur menghasilkan bahwa hipotesis pertama ditolak, hipotesis kedua ditolak, dan hipotesis ketiga diterima. Adapun hasil uji Anakova tersebut dapat terlihat pada Tabel 2 sebagai berikut.

Tabel 2. Hasil Uji Anacova terhadap Hasil Belajar Kognitif

\begin{tabular}{lcccc}
\hline \multicolumn{1}{c}{ Sumber } & Jumlah Kuadrat & $\mathrm{df}$ & $\mathrm{F}_{\mathrm{h}}$ & $\mathrm{p}$ (Sig.) \\
\hline Model pembelajaran & 5137,06 & $3: 146$ & 14,10 & 0,00 \\
$\begin{array}{l}\text { Kemampuan akademik } \\
\begin{array}{l}\text { Interaksi model } \\
\text { pembelajaran dengan }\end{array}\end{array}$ & 2075,15 & $1: 146$ & 17,09 & 0,00 \\
kemampuan akademik & 245,82 & $3: 146$ & 0,67 & 0,57 \\
\hline
\end{tabular}

Berdasarkan hasil uji Anacova pada Tabel 2 menunjukkan $\mathrm{H}_{0}$ ditolak pada hipotesis pertama terhadap hasil belajar kognitif, hal ini dapat disimpulkan bahwa ada pengaruh mahasiswa yang belajar menggunakan model pembelajaran kooperatif tipe STAD, Jigsaw II dan TGT terhadap hasil belajar kognitif dengan $($ sig. $=0,00) . \quad$ Berpengaruhnya model pembelajaran kooperatif terhadap hasil belajar kognitif disebabkan pembelajaran kooperatif mempunyai kelebihan dibandingkan dengan pembelajaran konvensional. Hal ini sesuai dengan teori Lord 2001 dalam Jufri (2010) mengidentifikasi 11 kategori umum kelebihan dari model pembelajaran kooperatif yakni; 1) peningkatan kemampuan berpikir, 2) pengembangan sikap positif terhadap pelajaran, 3) suasana akademik dan lingkungan belajar yang lebih konduktif, 4) variasi model asesmen, 5) peningkatan pemahaman mengenai hubungan teori dan praktek, 6) pengembangan kemampuan membaca dan menulis hasil kerja ilmiah, 7) pengembangan ketrampilan sosial dan bekerja sama, 8) Peningkatan kualitas hasil belajar, 9) pengembangan nilai-nilai dalam diri peserta didik, 10) pemodelan dunia nyata dalam kehidupan peserta didik, dan 11) pengembangan kesetaraan kesempatan antara peserta didik pria dan wanita. Orlich, et al (1998) menuliskan beberapa keuntungan dari model pembelajaran kooperatif adalah; 1) meningkatkan pemahaman mengenai materi inti pelajaran, memperkuat ketrampilan sosial, melatih siswa mengambil keputusan, menciptakan suasana belajar aktif, mengembangkan rasa percaya diri (self esteem ) peserta didik, mengakomodasi beragam gaya belajar, mengembangkan rasa tanggungjawab peserta didik, berfokus pada keberhasilan induvidu. Dengan demikian, pendidik harus memilih metode pembelajaran yang tepat untuk meningkatkan hasil belajar kognitif 
mahasiswa, salah satunya menggunakan model pembelajaran kooperatif.

Hasil penelitian ini didukung oleh penelitian terdahulu antara lain; Arizona (2013) yang menemukan bahwa peserta didik yang belajar melalui model pembelajran kooperatif tipe STAD berbeda signifikan pada aspek hasil belajar kognitif dibandingkan dengan peserta didik yang belajar dengan tipe NHT.Didukung pula oleh hasil penelitian Andriani, D.G. (2013) menyatakan bahwa ada perbedaan rerata yang signifikan antara peserta didik yang diterapkan model pembelajaran kooperatif tipe Jigsaw II dengan model pembelajaran langsung dan TPS (Think Phair Share), prestasi belajar matematika siswa yang dikenai model pembelajaran koopertif tipe Jigsaw II lebih baik dibandingkan pembelajaran langsung dan TPS. Selanjutnya hasil penelitian Tarigan dan Gultom (2012) menemukan bahwa ada pengaruh model pembelajaran koopertif tipe TGT terhadap hasil belajar IPA-Fisika peserta didik di kelas VII SMP Negeri I Percut Sei Tuan pada konsep pengukuran.

Berdasarkan hasil hipotesis kedua menunjukkan bahwa ada pengaruh mahasiswa yang memiliki kemampuan akademik tinggi dan rendah terhadap hasil belajar kognitif dengan $(p=0,00)$,sehingga dapat disimpulkan kesenjangan antara mahasiswa berkemampuan akademik tinggi dan rendah tidak ada perbedaan yang signifikan terhadap hasil belajar kognitif. Hasil penelitian ini sejalan dengan temuan Karmana (2011) yaitu ada pengaruh kemampuan akademik terhadap hasil belajar kognitif biologi. Didukung pula oleh hasil penelitian Ramdani (2012) menyatakan bahwa ada perbedaan hasil belajar IPA Biologi dan ketrampilan berpikir kritis antara siswa yang berkemampuan akademik atas dan bawah setelah mengikuti pembelajaran dengan strategi inkuiri level 1, level 2, level 3 dan strategi konvesional.

Hasil analisis data pada hipotesis ketiga pada penelitian ini menunjukkan tidak ada pengaruh interaksi antara model pembelajaran koperatif tipe STAD, Jigsaw II, dan TGT dengan kemampuan akademik terhadap hasil belajar kognitif mahasiswa program studi pendidikan Biologi semester IV STKIP Bima. Hasil penelitian ini sejalan dengan temuan Utami (2014) yaitu tidak ada interaksi model pembelajaran kooperatif berbasis pemberdayaan berpikir dan non model pembelajaran kooperatif berbasis pemberdayaan berpikir dengan kemampuan akademik terhadap hasil belajar IPA. Didukung pula oleh hasil penelitian Gayatri (2013) interaksi antara strategi pembelajaran kooperatif dengan kemampuan akademik 
peserta didik tidak berpengaruh terhadap kemampuan menyelesaikan masalah dan hasil belajar kognitif peserta didik ( $p$ > $0,05)$ yang berarti tidak ada pengaruh signifikan pada interaksinya.

\section{Uji Beda Pengaruh Antar Perlakuan} terhadap Hasil BelajarKognitif
Uji lanjut untuk mengetahui pengaruh beda nyata terkecil dari perlakuan model pembelajaran kooperatif terhadap hasil belajar kognitif, menggunakan uji LSD. Adapun hasil uji LSD pada model pembelajaran kooperatif terhadap hasil belajar kognitif dapat disajikan pada Tabel 3 sebagai berikut.

Tabel 3. Hasil uji LSD Antar Model Pembelajaran terhadap Hasil Belajar Kognitif

\begin{tabular}{lllcc}
\hline \multirow{4}{*}{ LSD } & Kelas Perlakuan & Kelas Perlakuan & Perbedaan rata-rata & Sig. \\
\cline { 2 - 5 } & Jigsaw II & TGT & $-11.3036^{*}$ & 0,000 \\
& & STAD & $6.3471^{*}$ & 0,034 \\
& & Konvesional & $8.6124^{*}$ & 0,006 \\
\cline { 2 - 5 } & TGT & STAD & $17.6507^{*}$ & 0,000 \\
& Konvesional & $19.9161^{*}$ & 0,000 \\
\cline { 2 - 5 } & STAD & Konvesional & 2.2654 & 0,463 \\
\hline
\end{tabular}

Berdasarkan Tabel 3 dapat simpulkan bahwa perlakuan model pembelajaran yang paling efektif terhadap hasil belajar kognitif yaitu, model pembelajaran kooperatif tipe TGT yang dibandingkan dengan model pembelajaran yang lain, karena nilai perbedaan rataratanya berkoofisien positif dan sig. < 0,05, kemudian diikuti oleh perlakuan model pembelajaran kooperatif tipe Jigsaw II, dan STAD. Hal ini berdasarkan observasi selama penelitian pada proses pembelajaran khusus pada sintaks turnamen akademik yang diimplementasikan oleh kelas model pembelajaran kooperatif tipe TGT, mempunyai karakteristik kuis yang tidak sama dengan kooperatif tipe STAD dan Jigsaw II yakni adanya game turnamen akademik yang mendudukkan mahasiswa berkemampuan akademik tinggi dan rendah pada meja turnamen yang terpisah, kemudian dilanjutkan dengan kuis permainan dan diberikan penghargaan pada kelompok dan induvidu yang mendapatkan skor tertinggi, sehingga pada nilai postest kelas model pembelajaran kooperatif lebih tinggi $(70,46)$, Jigsaw II $(59,16)$, dan STAD $(52,81)$.

Hasil Penelitian ini sejalan dengan penelitian Ahriani (2013) menyatakan terdapat perbedaan hasil belajar kimia antara peserta didik yang diajarkan dengan model pembelajaran kooperatif tipe STAD dengan peserta didik yang diajarkan dengan menggunakan model pembelajaran kooperatif tipe TGT pada materi pokok ikatan kimia, dengan nilai 
rata-rata hasil belajar peserta didik yang diajarkan dengan model pembelajaran kooperatif tipe TGT lebih tinggi daripada yang diajarkan dengan model pembelajaran kooperatif tipe STAD. Didukung pula dengan penelitian Widyasari (2012) menyatakan bahwa hasil belajar yang menggunakan model pembelajaran kooperatif tipe TGT lebih tinggi sebesar 79,97 dari pada STAD sebesar 78,23 dan lebih tinggi dari pembelajaran konvesional sebesar 68,93 yang berarti TGT lebih efektif dari STAD dan konvesional.

\section{KESIMPULAN}

Berdasarkan hasil penelitian dan uraian pembahasan yang telah disajikan, dapat disimpulkan beberapa hal sebagai berikut:

1. Model pembelajaran kooperatif tipe STAD, Jigsaw II, dan TGT berpengaruh signifikan terhadap hasil belajar kognitif mahasiswa program studi pendidikan Biologi semester IV STKIP Bima.

2. Kemampuan akademik berpengaruh signifikan terhadap hasil belajar kognitif mahasiswa program studi pendidikan Biologi semester IV STKIP Bima.

3. Interaksi antara model pembelajaran kooperatif tipe STAD, Jigsaw II, dan
TGT dengan kemampuan akademik tidak berpengaruh terhadap hasil belajar kognitif mahasiswa program studi pendidikan Biologi semester IV STKIP Bima.

4. Model pembelajaran kooperatif tipe TGT paling efektif dibandingkan dengan tipe Jigsaw II dan STAD.

\section{DAFTAR PUSTAKA}

Ahriani, F. 2013. Pengaruh Model Pembelajaran Kooperatif dan Gaya Belajar Terhadap Hasil Belajar Kimia Peserta didik Kelas X SMK Negeri 2 Bantaeng. Jurnal Chemica Vol.14 Nomor 1 Juni 2013, 1-9.

Andriani, D.G, Atmojo, T.K, dan Mardiyana. 2013. Eksperimentasi Model Pembelajaran Kooperatif Tipe Jigsaw II dan Think Pair Share ditinjau dari kecerdasan Emosional Siswa SMP se-kota Kediri Tahun Pelajaran 2012/2013. Jurnal Elekronika Pembelajaran Matematika. Vol. 1, No. 7, hal.651-660, Desember 2013. ISSN: 2339-1685.(online): http://jurnal.pasca.Uns.nc.id

Arizona, K. 2013. Pengaruh Implementasi Media Tiga Dimensi Kemagnetan Berbasis Inkuiri (MTDKBI) melalui Strategi Kooperatif terhadap Kecakapan Sosial, Sikap Ilmiah dan Hasil Belajar Kognitif Siswa SMP Kelas IX. Tesis: Universitas Mataram.

Direktorat Akademik Ditjen Dikti. 2008. Buku Panduan Pengembangan Kurikulum Berbasis Kompetensi Pendidikan Tinggi. Jakarta: Sub Direktorat KPS. 
Gayatri, I.G.A.S. 2014. Efektifitas Pembelajaran Berbasis Masalah (PBM) dan Strategi Kooperatif terhadap Kemampuan Menyelesaikan Masalah dan Hasil Belajar Kognitif Biologi Ditinjau dari Kemampuan Akademik Awal Siswa Kelas X SMAN. 3 Mataram. Tesis. Program studi Magister Pendidikan IPA, Program Pascasarjana Universitas Mataram.

Huda, M. 2012. Cooperatifve Learning metode, teknik, struktur dan model penerapan.Yogyakarta: Pustaka Pelajar.

Jufri, A. W. 2010. Belajar dan Pembelajaran Sains. Mataram Lombok: Arga puji press

Karmana, I. W. 2011. Starategi Pembelajaran, Kemampuan Akademik, Kemampuan Pemecahan Masalah, Dan Hasil Belajar Biologi. Jurnal Ilmu Pendidikan, Volome 17. Nomor. 5.2011 (online): http://journal.um.ac.id/index.php/j ip/article/view/2866.

Lembaran Negara RI Nomor 158 tahun 2012. Undang-Undang Republik Indonesia nomor 12 tahun 2012 tentang tujuan pendidikan tinggi: Jakarta Press.

Ramdani, A. 2012. Pengembangan Perangkat Pembelajaran Inkuiri melalui Kegiatan Lesson Studi dan Pengaruh Implementasinya terhadap Hasil Belajar IPA Biologi dan Ketrampilan Berpikir Kritis Siswa Berkemampuan Akademik Berbeda di SMP
Negeri Kota Mataram. Disertasi. Unirversitas Negeri Malang.

Sugiyono, 2012. Metode Penelitian Kuantitatif Kualitatif dan $R \& D$. Bandung: Alfabeta

Tarigan, R dan Gultom, V. 2012. Pengaruh Model Pembelajaran Kooperatif Tipe Teams Games Turnament Terhadap Hasil Belajar IPA Fisika di SMP Negeri Percut Sei Tuan.Skripsi.Universitas Negeri Medan.ISSN 2085-5281.

Trihendardi, C. 2009. Step by Step SPSS 18 Analisis Data Statistik. Yogyakarta: Penerbit ANDI.

Utami, S. D. 2014. Pengaruh Penerapan Model Pembelajarn Hasil Kooperatif Berbasis Pemberdayaan Berpikir terhadap Kemampuan Berpikir Kritis dan Hasil Belajar ditinjau dari Kemampuan Akademik Mahasiswa. Tesis. Program studi Magister Pendidikan IPA, Program Pascasarjana Universitas Mataram.

Widyasari, A.W. 2012. Komparasi Penggunaan Model Pembelajaran Kooperatif Tipe Team Game Tournament (TGT) dan Student Team Achiement Division (STAD) Terhadap Hasil Belajar IPA Biologi Siswa SMP Negeri 2 Lendah Tahun Ajaran 2011/2012. Skripsi. Program studi Pendidikan Biologi Fakultas Sains dan Teknologi Universitas Islam Negeri Sunan Kalijaga Jogjakarta.(Online):http://digilib.u insuka.ac.id/7927/1/BAB\%20I,\% $\underline{20 \mathrm{Vpdf}}$ 